\title{
植物へのカリウム供給源としての土壤微生物バイオマス 土壤微生物は㗌素やリンだけでなくカリウムも抱え込んでいる
}

カリウムは窒素, リンと並ぶ植物の三大必須栄養元素 の一つである. 光合成, 炭水化物の植物体内での転流, 気孔の開閉，膜電位の調節，細胞内の浸透圧や酵素機能 の維持など，植物の生育に不可欠な役割を果たしてい る。また，作物はカリウムの要求量が多く，その吸収量 は窒素に匹敵する ${ }^{(1)}$.土壤中のカリウムは，分析操作上 の便宜的な形態として，水溶性，交換性，非交換性に分 けられており，互いに平衡関係にある。植物が直接吸収 する形態は水溶性のカリウムイオンであり，その減少を 補うのが粘土鉱物などの負荷電に吸着した交換性のカリ ウムとされている（図1）。土壤中のカリウムの動態を 考える際には，イオンあるいは無機粒子に存在するカリ ウムの形態のみが想定されてきた。土畩中の生物はカリ ウムの動態にはかかわっていないのであろうか？ カリ ウムは生物の細胞内の主要な無機陽イオンであり, 細菌 や糸状菌の細胞では $0.18 〜 0.2 \mathrm{M}$ 以上と，細胞外に比べ 高い濃度が維持されている。そのため, 微生物体内に存 在するカリウム（微生物バイオマスカリウム）もまた， 土壤中のカリウムの動態にかかわる重要な形態の一つで あると考えられる

土壤中の窒素やリンの動態における微生物バイオマス の重要性は広く認識されている ${ }^{(2)}$. 土壤微生物は有機物 などを分解・無機化する過程で増殖・成長し, 炭素, 窒 素，リン，塩類などの養分の一部をバイオマスに取り込 む.それらの菌体が死滅すると微生物により分解され, バイオマス中の養分の一部が土壤中へ放出される.土壤 有機物, なかでも腐植物質の分解速度は極めて遅く, 半 減期が数千年以上の場合もある。それに対し，土壤微生 物バイオマスの分解速度は速く，代謝回転時間（turn over time）は年から月のオーダーである。土壤有機物 中に占める微生物バイオマスの割合は 2 〜 $3 \%$ に過ぎな いが，植物への可給態養分の供給に果たす微生物バイオ マスの役割は大きい.

微生物バイオマスは一般には大型の動物や植物根以外 の土壤中の全生物体量を指し, 細菌, 糸状菌などがその 大部分を占める。1976年にJenkinsonら (3)によって，土 壤をクロロホルム燻蒸で殺菌した後に無機化される炭素 を測定することにより，微生物バイオマス炭素量を求め
る方法（クロロホルム燻蒸法）が開発された。その後, 微生物バイオマス窒素やリンの測定法が考案され，研究 が大きく発展し，土壤中の養分の貯蔵・供給者として微 生物バイオマスの重要性が明らかにされてきた。

しかし，微生物バイオマスカリウムはほとんど注目さ れることはなく，見過ごされてきた。これには，微生物 バイオマスカリウムを直接定量する方法がなかったこと が大きな原因であったと思われる．土壤の微生物バイオ マス炭素量と純粋培養により求めた微生物細胞の平均的 な炭素とカリウムの比率から，バイオマスカリウム量を 計算により推定していたのである。ようやく最近になっ

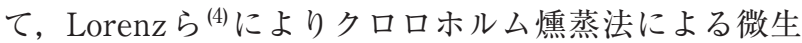
物バイオマスカリウムの測定法が確立された．Lorenz らはこの方法を用い，アメリカの畑土壤で微生物バイオ マスカリウム量を測定することにより，バイオマス中の カリウム量が交換性カリウム量の $37 \%$ に相当すること を明らかにし，土壤中のカリウムの貯蔵源としての微生 物バイオマスの重要性を示した.

水田を対象に土壤中の微生物バイオマスカリウム量を

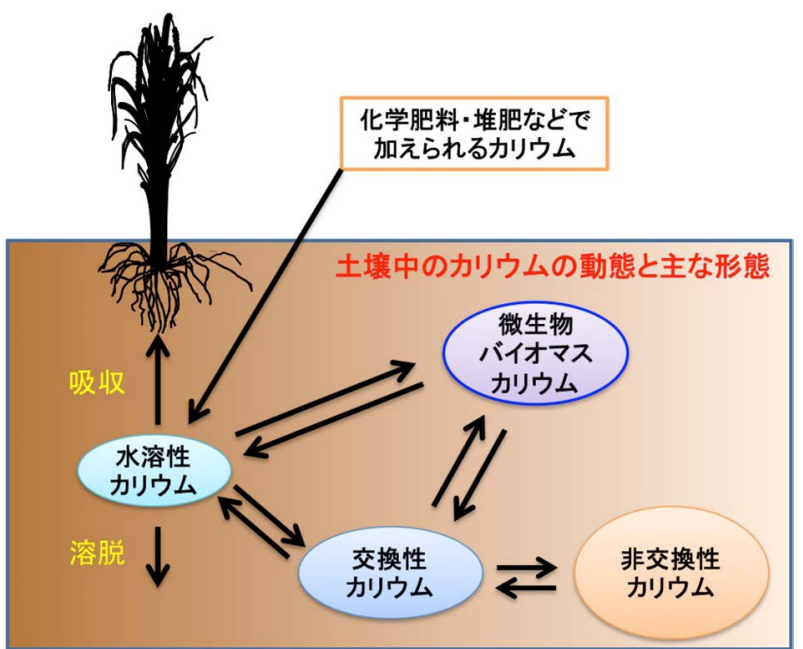

図 1 -土壤中のカリウムの動態と主な形態

これまでは, 微生物バイオマスカリウム以外の水溶性, 交換性, 非交換性の 3 形態のみが土袞中でのカリウムの動態にかかわって いると考えられていた．近年，直接定量する測定法が確立され， 微生物バイオマスカリウムは交換性カリウムの $27 \%$ に達するこ とが明らかとなった。 
測定した研究結果 ${ }^{(5)}$ を紹介しょう。水稲栽培中に経時的 に採取した水田土壤の微生物バイオマスカリウム量は 8〜 43 $\mathrm{mg} \mathrm{K} \mathrm{kg}^{-1}$ であり, 平均すると交換性カリウム量 の $27 \%$ に相当した。面積当たりの微生物バイオマスカ リウム量を試算すると $26 \mathrm{~kg} \mathrm{Kha}^{-1}$ となり，水稲への 1作あたりの施肥量 $\left(82 \mathrm{~kg} \mathrm{Kha}^{-1}\right)$ の $32 \%$ に相当した. また，土壤へのカリウムの補給源ともなる家畜ふん堆肥 や稲わら堆肥を長期間連年施用すると, 微生物バイオマ スカリウム量と交換性カリウム量は有機物無施用の土壌 よりも大きく増加した，興味深いことに，交換性カリウ ム量に対する微生物バイオマスカリウム量の割合は有機 物無施用の土畩でより大きく，特に，長期間カリウム施 肥を行わず，カリウムが欠そ状態にある土䁃では交換性 カリウム量より微生物バイオマスカリウム量のほうが大 きい值を示した。

カリウムには窒素やリンとは異なり有機態の化合物が ないこともあり，土壤中での動態への微生物の関与は意 識しにくいと思われる。紹介した研究結果は土壌中のカ リウムの動態に「微生物が抱え込んでいるカリウム」が かかわっていることを示唆しており，図1に示すように イオンや無機粒子に存在する形態だけでなく，微生物バ イオマスカリウムも考慮する必要がある．今後，微生物 バイオマスカリウムの代謝回転速度を測定することによ り，微生物バイオマスからのカリウムの流れを定量化 し，植物へのカリウムの供給源としての土壤微生物バイ オマスの重要性を明らかにしたい.

1) 尾和尚人：“肥料の事典”, 朝倉書店, 2006, p. 207.

2) 早野恒一：“新・土の微生物 (2)”, 博友社, 1997, p. 133.

3) D. S. Jenkinson \& D. S. Powlson: Soil Biol. Biochem., 8, 209 (1976).

\section{今日の話題}

4) N. Lorenz, K. Verdell, C. Ramsier \& R. P. Dick: Soil Sci. Soc. Am. J., 74, 512 (2010).

5) K. Yamashita, H. Honjo, M. Nishida, M. Kimura \& S. Asakawa: Soil Sci. Plant Nutr., 60, 512 (2014) (Corrigendum, 62, 570 (2016)).

(浅川 晋 $* 1$, 山下昂平 $* 1,2, * 1$ 名古屋大学大学院生命農 学研究科, $* 2$ 現在, 片倉コープアグリ株式会社)

\section{プロフィール}

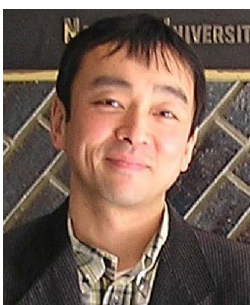

浅川 晋 (Susumu ASAKAWA)

$<$ 略歴 $>1985$ 年東京大学農学部農芸化学 科卒業／同年農林水産省九州農業試験場土 壤微生物研究室 $/ 1997$ 年科学技術庁長期在 外研究員（マックスプランク陸生微生物学 研究所) / 2001 年名古屋大学大学院生命農 学研究科助教授 $/ 2007$ 年同准教授 $/ 2013$ 年 同教授，現在に至る<研究テーマと抱負 $>$ 水田の土壤微生物学, 水田土壤中での微生 物の生き様の解明 $<$ 趣味 $>$ 鉄道小旅行（特 に路面電車), 地図の本を眺めること<所 属研究室ホームページ>http://www.agr. nagoya-u.ac.jp/ soil/Soil_Biology_and_ Chemistry/toppupeji.html

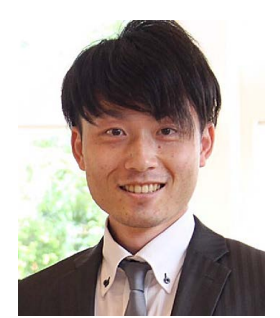

山下 昂平 (Kohei YAMASHITA)

$<$ 略歴 $>2012$ 年名古屋大学農学部応用生 命科学科卒業 / 2014 年同大学大学院生命 農学研究科博士前期課程修了/同年片倉 チッカリン株式会社（現片倉コープアグリ 株式会社) 入社, 現在に至るく研究テーマ と抱負>現在, 研究職ではない職種に就い ておりますく趣味>ゴルフ，スポーツ観戦 <所属研究室ホームページ>http://www. katakuraco-op.com/

Copyright (C) 2017 公益社団法人日本農芸化学会 DOI: 10.1271/kagakutoseibutsu.55.444 